\title{
Research Paper An economic study of post-harvest losses of banana in Durg district of Chhattisgarh
}

See end of the paper for authors' affiliations

Correspondence to : Archit Kumar Nayak Department of Agricultural Economics, Sam Higginbottom University of Agriculture, Technology and Sciences, Allahabad (U.P.) India

Email : archit.iabm@ gmail.com

Paper History :

Received : 01.11.2017;

Revised : 14.01.2018,

Accepted : 28.01.2018
ABSTRACT : An attempt has been made in the present study to estimate the physical post-harvest losses in banana and to identify the causes of losses in Durg district of Chhattisgarh. The explicit evaluation of the impact of post-harvest losses at different stages of marketing on farmers' net price, marketing costs, margins and efficiency have been presented. The results indicated that there are two major marketing channels viz., wholesaler channel and commission agent channel. The post-harvest losses were as high as $18 \mathrm{~kg}$ per quintal in the wholesale channel; comprising 31.67 per cent at the field and assembly level, 33.06 per cent at the wholesale market level and 35.28 per cent at the retail level. The total physical losses in the second marketing channel which was through commission agent were $18.95 \mathrm{~kg}$ per quintal with $28.50,33.25$ and 38.26 per cent in the corresponding stages. Small fruits, sun burn, harvesting injury and cracks and cankers at farm level; physiological dryness, physical damage and pressed and crushed fruits, over ripening loss at wholesale market level; physically damaged fruit and over ripened fruit at retailers level were the major causes responsible for post-harvest losses in banana. Further it was found that by separating out marketing loss at each stage of marketing, the producers' net share and wholesaler and retailer margins have been reduced substantially. It can be inferred that marketing efficiency is inversely proportional to the volume of post-harvest losses.

KEY Words : Post-harvest losses, Marketing channel, Banana growers, Farmers' net price, Marketing efficiency, Intermediaries' margin

How To Cite This Paper : Nayak, Archit Kumar, Singh, Nahar and Kumar, Dinesh (2018). An economic study of post-harvest losses of banana in Durg district of Chhattisgarh. Internat. Res. J. Agric. Eco. \& Stat., 9(1) : 8289, DOI : 10.15740/HAS/IRJAES/9.1/82-89. 